\title{
NOTES AND SCHEDAE TO LICHENES DELICATI EXSICCATI EDITAE IN MEMORIAM ANTONÍN VĚZDA (1920-2008), FASC. 5
}

\author{
E. FARKAS \\ Institute of Ecology and Botany, MTA Centre for Ecological Research, H-2163 Vácrátót, \\ Alkotmány u. 2-4, Hungary; E-mail: farkas.edit@okologia.mta.hu
}

(Received 5 November 2019; Accepted 10 December 2019)

Lichenes Delicati Exsiccati Editae of little, fine, special lichens is edited in honour of Antonín Vězda (1920-2008). The fifth fascicle of the exsiccate is consisted of 20 species of lichens and lichenicolous fungi and distributed to 12 lichen herbaria of the world. Collectors are K. Buaruang, D. Kalb, K. Kalb, G. E. Lee, L. Lőkös, A. Mertens, W. Polyiam, T. Pócs, W. Saipunkaew, D. Tang, N. Varga and E. Farkas.

Key words: exsiccate, lichenicolous fungi, lichens

\section{INTRODUCTION}

The current exsiccate series was initiated in 2010 to honour and express our gratitude to the late Dr Antonín Vězda (1920-2008), the Moravian lichenologist, - our Toni - on the occasion of the 90th anniversary of his birth (Farkas 2010). The contributions for the first fascicle were so rich that it became obvious very soon that LDEE will not remain as a single fascicle, but it needs continuation and so the second, third and fourth fascicle were published (Farkas 2011, 2014a, b) with 60 numbers until now. A new goal became outlined gradually - the numbers of the exsiccate is now planned to reach 100 by the time Toni would celebrate his 100th birthday, thus in 2020 two further fascicles are going to be edited and published, the present fifth fascicle and the forthcoming sixth fascicle, both with 20-20 numbers of species. Keeping the original idea - distributing delicate lichens and lichenicolous fungi - further collectors were invited for the following fascicles.

Among lichens of the current fifth fascicle there are more corticolous (7) and foliicolous (5) species, only some of them are saxicolous (3), terricolous (1), lignicolous (1) or muscicolous (1). Two representatives of lichenicolous fungi were also collected. The lichens and lichenicolous fungi originate from Europe (Bulgaria - 5, Portugal - 1, Romania - 5, Serbia - 1, Slovakia - 1, Sweden -1), Africa (Tanzania - 1), Asia (Malaysia - 2, Thailand -1) and Australia (2). Several specimens were collected in the Călimani National Park, Romania during field trips organised by the project "CRYPTIC: CRYPtogams" Traits In 
the Carpathians" (NKFI K119208), two of them in Mt Rețitiş near the meteorological station (Figs 1-2). Bulgarian sites were visited by the support of our Bulgarian-Hungarian academic cooperation. The National Nature Reserve Ostrov Kopáč was visited together with Anna Guttová and Anna Lackovičová on the occasion of a joint field trip in the framework of our Slovakian-Hungarian academic cooperation (Fig. 3).

The contributors are collectors and determinators in alphabetical order: E. Farkas (Vácrátót, Hungary), K. Buaruang (Bangkok, Thailand), D. and K. Kalb (Neumarkt, Germany), G. E. Lee (Malaysia), L. Lőkös (Budapest, Hungary), R. Lücking (Berlin, Germany), A. Mertens (Pfaffenhofen, Germany), W. Polyiam (Bangkok, Thailand), T. Pócs (Eger, Hungary), W. Saipunkaew (Chiang Mai, Thailand), D. Tang (Malaysia), N. Varga (Vácrátót, Hungary). TLC and HPTLC analyses were carried out by E. Farkas, K. Kalb, N. Varga and K. Veres.

The 20 specimens of the fifth fascicle have been distributed to the following 12 herbaria (for herbarium acronyms see Index Herbariorum online
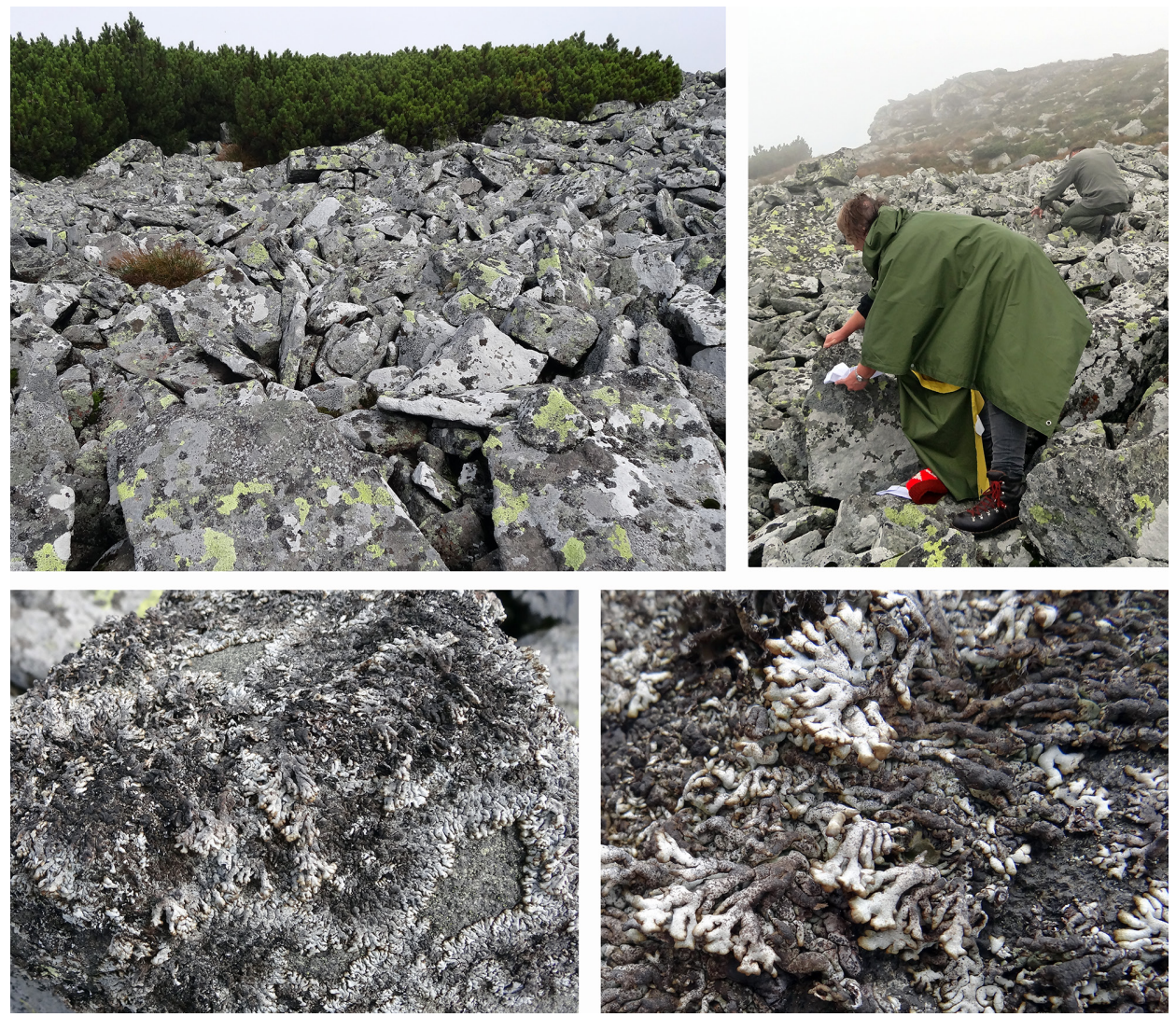

Fig. 1. Collecting Brodoa atrofusca in the Călimani National Park, Romania, in Mt Reţitiş near the meteorological station 


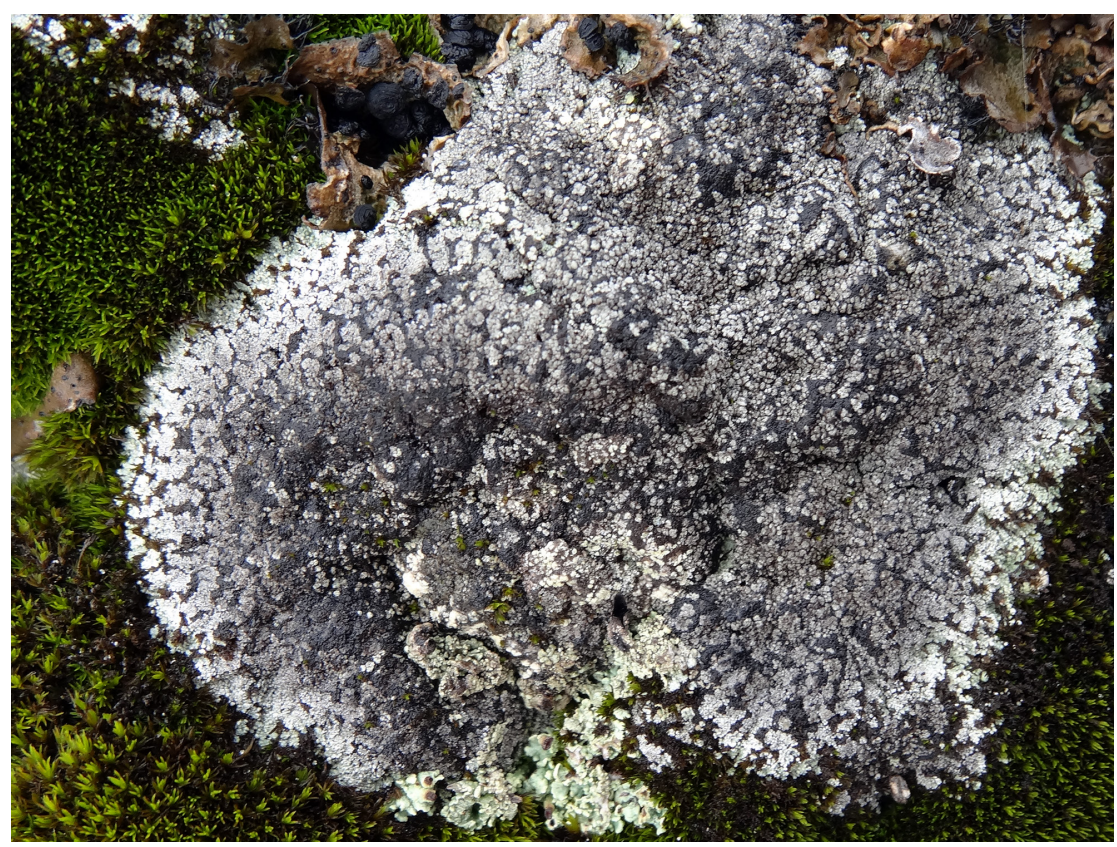

Fig. 2. Lepraria neglecta, collected in the Călimani National Park, Mt Rețitiş, Romania, near the meteorological station

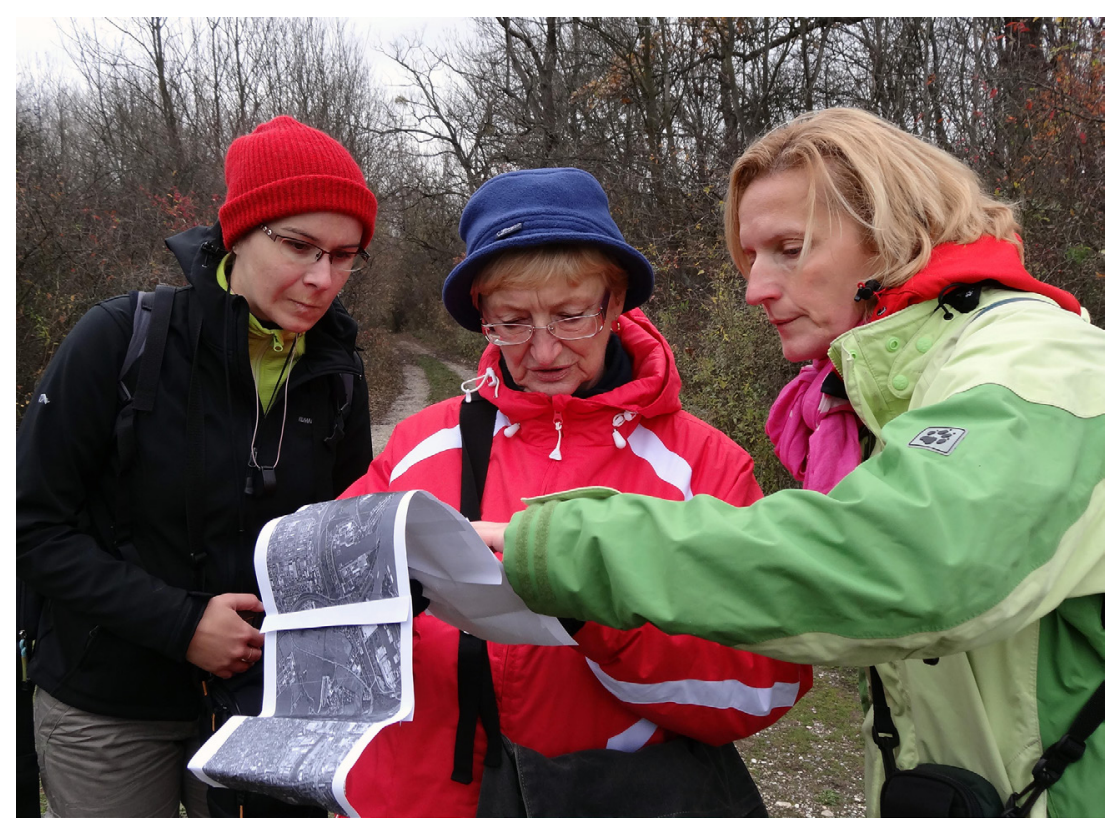

Fig. 3. Nóra Varga, Anna Lackovičová and Anna Guttová in the National Nature Reserve Ostrov Kopáč, Slovakia, habitat of Clypeococcum hypocenomycis 
(Thiers 2019)): 1. BM = London, United Kingdom; 2. BP = Budapest, Hungary; 3. $\mathrm{F}=$ Chicago, USA; 4 . hb. Flakus $=$ Kraków, Poland; 5. hb. Kalb $=$ Neumarkt, Germany; 6. HO = Hobart, Tasmania/Australia; 7. KRAM= Kraków, Poland; 8 . PRA-V = Průhonice, Czech Republic; 9. SAV = Bratislava, Slovakia; 10. STU = Stuttgart, Germany; 11. UPS = Uppsala, Sweden; 12. VBI = Vácrátót, Hungary. Specimens of incomplete sets have been presented to some other herbaria.

Schedae containing names of species, their authors with further annotations, collecting data and remarks (e.g. chemical content) are listed below.

\section{EDIT FARKAS: LICHENES DELICATI EXSICCATI EDITAE}

In memoriam Antonín Vězda (1920-2008)

Fasc. 5 (No. 61-80)

Spring 2020

\section{Bacidia fraxinea Lönnr.}

in Flora, Jena 41: 612, 1858.

BULGARIA. Burgas Province, Malko Tarnovo Municipality, Strandzha Mts, Dokuzak stream at Sredoka reserve near Stoilovo village, on bark (Salix).

Lat.: $42^{\circ} 00^{\prime} 59.37^{\prime \prime} \mathrm{N}$; Long.: $27^{\circ} 30^{\prime} 20.24^{\prime \prime} \mathrm{E} \quad$ Alt.: ca $260 \mathrm{~m} \mathrm{s.} \mathrm{m}$.

Leg.: L. Lőkös

Dat.: 7 June 2009

Det.: L. Lőkös

\section{Brodoa atrofusca (Schaer.) Goward}

in The Bryologist 89(3): 222, 1987. - Basionym: Parmelia ceratophylla var. atrofusca Schaer., Enum. critic. lich. europ. (Bern): 42, 1850.

ROMANIA. Suceava County, Șaru Dornei commune, Gura Haitii, Călimani Mts, Călimani National Park, Mt Rețitiş near the meteorological station, on siliceous rock.

Lat.: $47^{\circ} 05^{\prime} 50.00^{\prime \prime} \mathrm{N}$; Long.: $25^{\circ} 14^{\prime} 34.61^{\prime \prime} \mathrm{E} \quad$ Alt.: ca 1,990 m s. m.

Leg.: E. Farkas and L. Lőkös

Dat.: 30 July 2018

Det.: E. Farkas and L. Lőkös

Atranorin, physodic acid, protocetraric acid present (HPTLC: E. Farkas and K. Veres, 2018).

Brodoa Goward, Bryologist 89(3): 222, 1987; named after the Canadian lichenologist Irwin M. Brodo (born 1935), who is the author of the book Lichens of North America (Brodo et al. 2001); owner of the Acharius Medal donated by IAL (1994). 


\section{Calicium tigillare (Ach.) Pers.}

in Ann. Wetter. Gesellsch. Ges. Naturk. 2: 14, 1811. - Basionym: Lichen tigillaris Ach., Lich. suec. prodr., Linköping: 67, 1799. - Synonym: Cyphelium tigillare (Ach.) Ach., in K. Vetensk-Acad. Nya Handl. 3: 261, 1815.

ROMANIA. Harghita County, Toplița municipality, Călimani Mts, near Vf. Alb, ca $13 \mathrm{~km}$ SW of Drăgoiasa, along the forest road, on lignum.

Lat.: $47^{\circ} 05^{\prime} 34.78^{\prime \prime} \mathrm{N}$; Long.: $25^{\circ} 18^{\prime} 14.44^{\prime \prime} \mathrm{E}$

Alt.: $c a 1,550$ m s. m.

Leg.: E. Farkas and L. Lőkös

Dat.: 30 July 2018

Det.: E. Farkas and L. Lőkös

Epanorin, rhizocarpic acid present (HPTLC: E. Farkas and K. Veres, 2018).

\section{Calopadia fusca (Müll. Arg.) Vězda}

in Folia geobot. phytotax. 21(2): 215, 1986. - Basionym: Lopadium fuscum Müll. Arg., Flora, Regensburg 64(7): 108, 1881.

AUSTRALIA. Queensland, Atherton Tableland, foothills of Mount Lewis, Julatten between Mount Molloy and Mossman, Kingfisher Lodge; in a very disturbed remnant of a tropical rainforest. On leaves.

Lat.: $16^{\circ} 35^{\prime} 44^{\prime \prime}$ S; Long.: $145^{\circ} 20^{\prime} 23^{\prime \prime} \mathrm{E} \quad$ Alt.: ca $420 \mathrm{~m} \mathrm{s.} \mathrm{m.}$

Leg.: K. and D. Kalb $41168 \quad$ Dat.: 23-24 August 2008

Det.: K. Kalb; Conf.: R. Lücking

\section{Canoparmelia texana (Tuck.) Elix et Hale}

in Elix, Johnston and Verdon, Mycotaxon 27: 279, 1986. - Basionym: Parmelia texana Tuck., Amer. J. Sci. Arts, Ser. 2, 25: 424, 1858.

TANZANIA. Morogoro District, S Uluguru Mts, along the road, $1 \mathrm{~km} \mathrm{E} \mathrm{of}$ Chenzema village. Open granitic rocks in Nyambutwa valley near the falls.

Leg.: T. Pócs 88260/V

Alt.: $c a 1,700 \mathrm{~m} \mathrm{s.} \mathrm{m}$.

Det.: E. Farkas and L. Lőkös

Dat.: 27 October 1988

Atranorin, divaricatic acid, nordivaricatic acid present (HPTLC: E. Farkas and K. Veres, 2019).

\section{Chaenotheca phaeocephala (Turner) Th. Fr.}

in Ann. Bot. (Usteri) 7: 20, 1794. - Basionym: Lichen phaeocephalus Turner, Trans. Linn. Soc., London 9: 260, 1808. 
SWEDEN. Östergotland province. Vadstena parish, on bark (Tilia).
Lat.: $58^{\circ} 27^{\prime} 05.6^{\prime \prime} \mathrm{N}$; Long.: $14^{\circ} 53^{\prime} 29.9^{\prime \prime} \mathrm{E}$
Alt.: ca 97 m s. m.
Leg.: E. Farkas and N. Varga
Dat.: 13 August 2013
Det.: E. Farkas and N. Varga

67. Clypeococcum hypocenomycis D. Hawksw.

in Notes R. bot. Gdn Edinb. 38(1): 167, 1980.

SLOVAKIA. Podunajská nížina lowland, Bratislava, National Nature Reserve Ostrov Kopáč. Parasitic on the thallus of Hypocenomyce scalaris on a burnt pine stump.

Lat.: $48^{\circ} 05^{\prime} 37.6^{\prime \prime} \mathrm{N}$; Long.: $17^{\circ} 09^{\prime} 43.1^{\prime \prime} \mathrm{E}$

Alt.: ca 124 m s. m.

Leg.: E. Farkas and N. Varga

Dat.: 14 November 2013

Det.: N. Varga

68. Coenogonium subluteum (Rehm) Kalb et Lücking

in Lücking and Kalb, Bot. Jb. 122(1): 34, 2000. - Basionym: Biatorina sublutea Rehm, Philipp. J. Sci., C, Bot. 8(5): 404, 1913.

MALAYSIA. Kelantan, Tok Bali Bay, near the estuary, $3 \mathrm{~km}$ ENE of Pasir Puteh District Council. On leaves in swamp forest.

Lat.: $05^{\circ} 51^{\prime} 08^{\prime \prime} \mathrm{N}$; Long.: $102^{\circ} 26^{\prime} 20^{\prime \prime} \mathrm{E} \quad$ Alt.: ca 2-3 m s. m.

Leg.: T. Pócs, G. E. Lee, D. Tang, $13185 \quad$ Dat.: 8 November 2013

Det.: E. Farkas

69. Haematomma nemetzii J. Steiner

in Denkschr. Kaiserl. Akad. Wiss. Wien, Math.-Naturwiss. Kl. 68: 230, tab. I, fig. 4a-c, 1899.

BULGARIA. Haskovo Province, Madzharovo Municipality, Eastern Rhodope Mts, E side of 'Momina Skala', at Arda river near Madzharovo, rocky area near an abandoned mine, on acidic rocks.

Lat.: $41^{\circ} 38^{\prime} 23.25^{\prime \prime} \mathrm{N}$; Long.: 2550 50.31" E Alt.: ca $170 \mathrm{~m}$ s. m.

Leg.: N. Varga and L. Lőkös D Dat.: 13 June 2019

Det.: E. Farkas

Atranorin, psoromic acid and porphyrilic acid present (HPTLC: E. Farkas and K. Veres, 2019). 


\section{Lecanactis abietina (Ach.) Körb.}

in Syst. lich. germ. Breslau: 275, 1855. - Basionym: Lichen abietinus Ach., K. Vetensk-Acad. Nya Handl. 16(3): 139, 1795.

ROMANIA. Suceava County, Poiana Stampei commune, along the trail in the peat-bog 'Tinovul Mare' at Căsoi, on bark of Picea abies.

Lat.: $47^{\circ} 17^{\prime} 40.38^{\prime \prime} \mathrm{N}$; Long.: 25 07' 10.59" E $\quad$ Alt.: ca 920 m s. m.

Leg.: L. Lőkös

Dat.: 12 August 2019

Det.: E. Farkas and L. Lőkös

Lecanoric acid, schizopeltic acid present (HPTLC: E. Farkas and K. Veres, 2019).

\section{Lepraria neglecta (Nyl.) Erichsen}

in Flechtenfl. Nordwestdeutschl.: 394, 1957. - Basionym: Lecidea neglecta Nyl., Ann. Sci. Nat. Bot. 11: 233, 1859.

ROMANIA. Suceava County, Șaru Dornei commune, Gura Haitii, Călimani Mts, Călimani National Park, Mt Rețitiş near the meteorological station, on bryophytes on siliceous rock.

Lat.: $47^{\circ} 05^{\prime} 50.00^{\prime \prime} \mathrm{N}$; Long.: $25^{\circ} 14^{\prime} 34.61^{\prime \prime} \mathrm{E} \quad$ Alt.: ca 1,990 m s. m. Leg.: E. Farkas and L. Lőkös Dat.: 30 July 2018

Det.: E. Farkas and L. Lőkös

Alectorialic acid, angardianic/roccellic acid present (HPTLC: E. Farkas and N. Varga, 2019).

\section{Micarea prasina Fr.}

in Syst. orb. veg., Lund, 1: 256, 1825.

BULGARIA. Kardzhali Province, Kirkovo Municipality, Eastern Rhodope Mts, near Yakovitza, along a forest road in pine forest, on bark of Pinus nigra.

Lat.: $41^{\circ} 18^{\prime} 31.39^{\prime \prime} \mathrm{N}$; Long.: $25^{\circ} 15^{\prime} 07.40^{\prime \prime} \mathrm{E}$

Alt.: ca 750 m s. m.

Leg.: L. Lőkös and N. Varga

Dat.: 17 June 2019

Det.: E. Farkas and L. Lőkös

\section{Myriostigma candidum Kremp.}

in Lich. Foliic. Leg. Beccari: 22, 1874 [as 'candicum']. - Synonym: Cryptothecia candida (Kremp.) R. Sant., Symb. bot. upsal. 12(1): 65, 1952. 
MALAYSIA. Borneo Island, Sabah, Kota Kinabalu, Lok Kawi Wildlife Park ca $25 \mathrm{~km} \mathrm{SSW}$ of Kota Kinabalu, in remnants of a secondary rainforest. On leaves.

Lat.: $05^{\circ} 50^{\prime} 39^{\prime \prime} \mathrm{N}$; Long.: $116^{\circ} 04^{\prime} 00^{\prime \prime} \mathrm{E}$

Alt.: ca $30 \mathrm{~m} \mathrm{s.} \mathrm{m.}$

Leg.: K. Kalb and A. Mertens 41166

Dat.: 7 August 2014

Det.: K. Kalb; Conf.: R. Lücking

The type specimen of this species was collected by O. Beccari on Sarawak, Borneo Island in 1866, Beccari 224aa (M - lectotype, designated by Lücking et al., Lichenologist 38(3): 236, 2002).

74. Ochrolechia arborea (Kreyer) Almb.

in Bot. Notiser: 254, 1949. - Basionym: Variolaria lactea f. arborea Kreyer, Acta Horti Petropolit. 31: 321, tab. I, fig. 16-17, 1913.

ROMANIA. Suceava County, Poiana Stampei commune, along the trail in the peat-bog 'Tinovul Mare' at Căsoi, on Alnus bark.

Lat.: $47^{\circ} 18^{\prime} 03.65^{\prime \prime} \mathrm{N}$; Long.: $25^{\circ} 06^{\prime} 43.88^{\prime \prime} \mathrm{E}$

Alt.: ca 910 m s. m.

Leg.: L. Lőkös

Dat.: 6 August 2019

Det.: E. Farkas and L. Lőkös

75. Placynthiella uliginosa (Schrad.) J. R. Laundon

in Lichenologist 16(3): 245, 1984. -Basionym: Lichen uliginosus Schrad., Spicil.fl. germ. 1: 88, 1794. BULGARIA. Haskovo Province, Ivaylovgrad Municipality, Eastern Rhodope Mts, along the road 5906 near Kazak, acidophilous grassland area with scattered oak trees, on Quercus bark.

Lat.: $41^{\circ} 24^{\prime} 45.89^{\prime \prime} \mathrm{N}$; Long.: 25 53' 09.93" E Alt.: ca 385 m s. m.

Leg.: L. Lőkös and N. Varga

Dat.: 15 June 2019

Det.: E. Farkas and L. Lőkös

76. Plectocarpon lichenum (Sommerf.) D. Hawksw.

in Hawksworth and Galloway, Lichenologist 16(1): 86, 1984. - Basionym: Dothidea lichenum Sommerf., Suppl. Fl. lapp., Oslo: 224, 1826.

SERBIA. Pirot District, Crni Vrh, Jabučko Ravnište, Stara Planina Mts, near ski tracks at Hotel Stara Planina, in a beech forest. On the thalli of Lobaria pulmonaria growing on the bark of an old Fagus sylvatica.

Lat.: $43^{\circ} 21^{\prime} 50.08^{\prime \prime} \mathrm{N}$; Long.: $22^{\circ} 35^{\prime} 23.02^{\prime \prime} \mathrm{E}$

Alt.: ca $1,515 \mathrm{~m} \mathrm{s.} \mathrm{m}$.

Leg.: N. Varga and L. Lőkös

Dat.: 22 June 2019

Det.: N. Varga 
77. Tapellaria epiphylla (Müll. Arg.) R. Sant.

in Thorold, J. Ecol. 40: 129, 1952. - Basionym: Lopadium epiphyllum Müll. Arg., Flora, Regensburg 64(7): 107, 1881.

PORTUGAL. Madeira Island, Municipality Santana, along the Leveda do Furado ca $3 \mathrm{~km}$ from Ribeiro Frio towards Portela (EMC17 excursion "2"). On leaves in laurel forest dominated by Laurus novocanariensis, Clethra arborea, Ocotea foetens, Persea indica.

Lat.: $32^{\circ} 44^{\prime} 07.44^{\prime \prime} \mathrm{N}$; Long.: $16^{\circ} 51^{\prime} 56.88^{\prime \prime} \mathrm{W}$

Alt.: $c a 820 \mathrm{~m} \mathrm{s.} \mathrm{m.}$

Leg.: N. Varga

Dat.: 23 September 2015

Det.: E. Farkas

\section{Tephromela alectoronica Kalb}

in Türk, John and Hauck (eds), Sauteria 15: 243, 2008.

AUSTRALIA. Queensland, Eungella, $c a 60 \mathrm{~km}$ of Mackay, surrounding of Broken River Lodge, Rainforest Discovery Walk in a tropical rainforest. On bark.

Lat.: $21^{\circ} 10^{\prime} 03^{\prime \prime}$ S; Long.: $148^{\circ} 30^{\prime} 14^{\prime \prime} \mathrm{E}$

Alt.: ca 700 m s. m.

Leg.: K. and D. Kalb 40620

Dat.: 13 August 2015

Det.: K. Kalb

Atranorin, alectoronic acid present (TLC: K. Kalb, 2015).

\section{Trichothelium bipindense F. Schill.}

in Hedwigia 67: 278, 1927.

THAILAND. Chiang Mai province, Lumphun, Mae On, ESE of Chiang Mai, descent from Doi Mon Larn to Mae Kam Pong village, in an evergreen mountain forest dominated by Lithocarpus, Quercus, Castanopsis. On leaves.

Lat.: $18^{\circ} 51^{\prime} 22^{\prime \prime} \mathrm{N}$; Long.: $99^{\circ} 22^{\prime} 02^{\prime \prime} \mathrm{E}$

Alt.: ca 1,500 m s. m.

Leg.: K. Kalb, W. Saipunkaew (Om) and

Dat.: 19 March 2008

K. Buaruang (Nhong) and W. Polyiam (Pod) 41167

Det.: K. Kalb; Conf.: R. Lücking

\section{Vahliella leucophaea (Vahl) P. M. Jørg.}

in Lichenologist 40(3): 224, 2008. - Basionym: Lichen leucophaeus Vahl, Icon. Plant. Dan. 6(16): 8, 1787 . 
BULGARIA. Kardzhali Province, Krumovgrad Municipality, Eastern Rhodope Mts, along the road (no. 5906) between Kazak and Chernichevo, on acid soil at road bank.

Lat.: $41^{\circ} 21^{\prime} 49.39^{\prime \prime} \mathrm{N}$; Long.: $25^{\circ} 50^{\prime} 08.14^{\prime \prime} \mathrm{E}$

Leg.: N. Varga and L. Lőkös

Det.: L. Lőkös

Alt.: ca $650 \mathrm{~m} \mathrm{s.} \mathrm{m.}$

Dat.: 15 June 2019

Acknowledgements - The author is grateful to all contributors (whose names are mentioned above in the text) without whom the compilation of the exsiccate would not have been possible. The work was supported by various projects of the Hungarian Scientific Research Fund (OTKA T047160, K81232), of the Hungarian and Slovakian Academies of Sciences (Mobility project SNK40/2013), of the Hungarian and Bulgarian Academies of Sciences (Mobility project NKM47/2019) and of the Hungarian National Research Development and Innovation Fund (NKFI K124341, NKFI K119208).

\section{REFERENCES}

Brodo, I. M., Sharnoff, S. D. and Sharnoff, S. (2001): Lichens of North America. - Yale University Press, New Haven \& London, 795 pp.

Farkas, E. (2010): Notes and schedae to Lichenes Delicati Exsiccati Editae in memoriam Antonín Vězda (1920-2008), fasc. 1. - Acta Bot. Hung. 52(3-4): 331-340.

Farkas, E. (2011): Notes and schedae to Lichenes Delicati Exsiccati Editae in memoriam Antonín Vězda (1920-2008), fasc. 2. - Acta Bot. Hung. 53(1-2): 101-109.

Farkas, E. (2014a): Notes and schedae to Lichenes Delicati Exsiccati Editae in memoriam Antonín Vězda (1920-2008), fasc. 3. - Acta Bot. Hung. 56(1-2): 69-76.

Farkas, E. (2014b): Notes and schedae to Lichenes Delicati Exsiccati Editae in memoriam Antonín Vězda (1920-2008), fasc. 4. - Acta Bot. Hung. 56(3-4): 305-317.

Thiers, B. (2019): Index Herbariorum: A global directory of public herbaria and associated staff. New York Botanical Garden's Virtual Herbarium. - http://sweetgum.nybg.org/ih/

Open Access statement. This is an open-access article distributed under the terms of the Creative Commons Attribution 4.0 International License (https://creativecommons.org/ licenses/by/4.0/), which permits unrestricted use, distribution, and reproduction in any medium, provided the original author and source are credited, a link to the CC License is provided, and changes - if any - are indicated. (SID_1) 